\title{
BENTUK PINTU MASUK SARANG TRIGONA SPP DI KAWASAN HUTAN MANGROVE SURYA PERDANA MANDIRI KELURAHAN SETAPUK BESAR SINGKAWANG UTARA
}

\author{
(The Shape of Nest Entrance Trigona spp in the Surya Perdana Mandiri Mangrove Forest Area \\ at Setapuk Besar Village North Singkawang)
}

\author{
Febrianti, Iskandar AM, Muflihati \\ Fakultas Kehutanan Universitas Tanjungpura, JL. Daya Nasional Pontianak, 78124 \\ e-mail: febri.fahutan28@gmail.com
}

\begin{abstract}
The Trigona spp (kelulut) bee is a non-stinging honey bee that belongs to the Apidae family. Kelulut is a social insect that lives in groups in a colony, where this bee colony defends itself by biting if disturbed. Kelulut usually make nests in tree holes, wall gaps and bamboo holes in the house, with simple materials that are used as nests such as wooden boxes, pieces of bamboo, coconut fruit, coconut shells, and earthen pots as long as the nesting material is tightly closed. Bee hives are a place of refuge for a bee colony from bacteria, fungi, viruses, and predators, as well as a place for honey, bee pollen, and bee eggs to grow. Kelulut nests are built from resin material derived from plants, besides that there is a door to the nest which is decorated with a funnel made of resin and has various shapes, some are short and some are long, depending on the type which serves as a place to enter and exit colony members. The entrance and exit of the nest not only serves as a pathway for entry and exit, but also serves as a marker for the nest. Kelulut nest entrances have various shapes, including funnel, oval, elliptical, round and irregular or without protrusions at the entrance. This study aims to determine the shape of the entrance to the Trigona spp nest in the Surya Perdana Mandiri Mangrove Forest Area. The method used is a survey, with roaming techniques. Observations were made on trees with kelulut nests. Data analysis using descriptive qualitative. The results found 2 species of kelulut, namely Heterotrigona itama Cockerell and Tetragonula laeviceps Smith. H.itama bees have 6 the shape of entrance and T.laeviceps bees have 4 the shape of entrance. H.itama bees have a funnel at the entrance and there are propolis around the nest. The H.itama entrance has a different shape in the form of a long and slender funnel and a short and large funnel. In addition, the funnel has a variety of colors, black, golden yellow, light brown, and dark brown. While T.laeviceps species do not have a funnel or nest entrance. This type only makes a hole as a place to enter and exit the nest and there is no propolis found around the nest.
\end{abstract}

Keywords: Heterotrigona, mangrove, nest entrance, tetragonula, trigona.

\section{PENDAHULUAN}

Lebah terbagi menjadi dua kelompok besar, yaitu kelompok lebah yang bersengat dan kelompok lebah yang tidak bersengat. Genus Apis merupakan jenis lebah bersengat, dan sangat baik dalam menghasilkan madu, sedangkan Genus Trigona merupakan lebah tidak bersengat, yang sebelumnya tidak popular karena menghasilkan madu yang lebih sedikit dibandingkan Genus Apis (Kapitanhitu et al. 2018), akan tetapi produk lebah Trigona spp menjadi popular sebab mampu menghasilkan bee propolis yang memiliki multi khasiat (Manuhuwa et al 2013). 
Trigona spp merupakan salah satu spesies lebah penghasil madu dari Ordo Hymenoptera, Famili Apidae mempunyai tubuh yang berukuran kecil dan merupakan salah satu serangga pollinator penting (Priccilia et al 2018). Trigona spp termasuk kedalam serangga sosial yang hidup berkelompok dalam suatu koloni, dimana koloni lebah ini membela diri dengan cara menggigit jika terganggu. Koloni lebah kelulut terdiri atas golongan reproduktif (lebah jantan dan ratu) dan golongan non reproduktif (lebah pekerja) (Syafrizal et al 2012). Indonesia memiliki beberapa nama daerah untuk lebah Trigona sp., yaitu kelulut (Kalimantan), galo-galo (Sumatera), klanceng, lenceng (Jawa), teuweul (Sunda) (Azlan et al 2016). Kelulut ini sangat membantu dalam proses penyerbukan di alam terutama dihutan-hutan. Koloni kelulut banyak ditemukan bersarang di hutan-hutan, di rumah-rumah penduduk, lubang-lubang pohon dan rongga-rongga batu (Priccilia $e t$ al 2018). Sarang lebah merupakan tempat perlindungan bagi koloni lebah dari serangan bakteri, jamur, virus, maupun predator, serta tempat produksi madu, bee pollen dan tempat tumbuh kembang telur lebah (Yuliana et al 2015).

Keberadaan sarang kelulut ditandai dengan bangunan unik yang berfungsi sebagai pintu masuk dan keluarnya koloni lebah di sarang tersebut. Bentuk pintu keluar masuknya sarang kelulut sangat beragam, seperti berbentuk corong, bulat tak beraturan, atau tanpa tonjolan pada pintunya tersebut serta memiliki struktur tepi yang lengket. Pintu masuk dan keluarnya sarang tidak hanya berfungsi sebagai sebagai jalan untuk keluar dan masuk, akan tetapi juga berfungsi sebagai penanda sarang. Pintu masuknya sarang tersusun dari berbagai eksudat/resin getah pohon, campuran serbuk-serbuk kayu, dan batu-batuan kecil, yang berguna sebagai alat pertahanan terhadap serangan predator. Masing-masing bahan dasar penyusun pintu masuknya sarang berbedabeda pada tiap jenis lebah, dengan bentuk, warna, dan aroma yang dipengaruhi oleh jenis tumbuhan sumber resinnya, atau dipengaruhi oleh sumber pakan lebah kelulut tersebut (Syafrizal et al 2014). Selain itu, sarang kelulut tersusun atas beberapa bagian, dimana setiap bagian digunakan untuk menyimpan madu, karangan-karangan bola berisi telur, tempayak dan kepompong, serta dibagian sudut terdapat bola-bola hitam untuk menyimpan madu dan tepung sari (Sadam et al 2016).

Salah satu jenis kelulut yaitu Heterotrigona itama telah dikembangkan di hutan mangrove oleh kelompok masyarakat di Desa Batu Ampar Kalimantan Barat. Pengembangan madu pada hutan mangrove merupakan aspek yang bagus, sebab di hutan mangrove memiliki keragaman jenis mangrove yang cukup tinggi, dan sebagian besar jenis mangrove memiliki bunga yang mengandung pollen dan nektar sebagai sumber makanan bagi koloni kelulut. Selain itu, waktu pembungaan jenis-jenis mangrove umumnya berbeda antara satu dan lainnya, bahkan beberapa jenis diantaranya berbunga sepanjang tahun, sehingga menjamin ketersediaan sumber 
pakan bagi lebah madu (Hidayatullah 2016).

Hutan Mangrove Setapuk Besar, Kota Singkawang merupakan salah satu hutan mangrove di Indonesia yang dikelola oleh Perkumpulan Swadaya Peduli Mangrove (PSPM). Saat ini masyarakat bersama PSPM telah membudidayakan lebah kelulut di dalam stup yang diambil dari koloni sarang alami. Selain budidaya, masih terdapat lebah yang berada di dalam pohon. Pada kawasan hutan mangrove ini belum diketahui tentang bentuk pintu masuk sarang kelulut. Oleh sebab itu, penelitian ini dilakukan untuk mendata bentuk pintu masuk sarang Trigona spp di Kawasan Hutan Mangrove Setapuk Besar, Kabupaten Singkawang Utara, serta diharapkan dapat memberikan informasi dan menambah ilmu pengetahuan tentang bentuk pintu masuk sarang Trigona spp.

\section{METODOLOGI PENELITIAN}

Penelitian ini dilakukan di Kawasan Hutan Mangrove Surya Perdana Mandiri Kelurahan Setapuk Besar Singkawang Utara selama \pm 1 bulan. Alat yang digunakan antara lain ATK, kamera, kaliper, GPS, dan peta lokasi. Bahan atau obyek penelitian adalah sarang lebah kelulut. Penelitian ini menggunakan metode survey, dengan teknik jelajah. Pengamatan dilakukan pada pohon mangrove yang terdapat sarang kelulut. Sarang yang sudah ditemukan dilihat bentuk pintu masuknya, selanjutnya dilakukan pengamatan dan pengukuran. Analisis data yang digunakan yaitu deskriptif kualitatif.

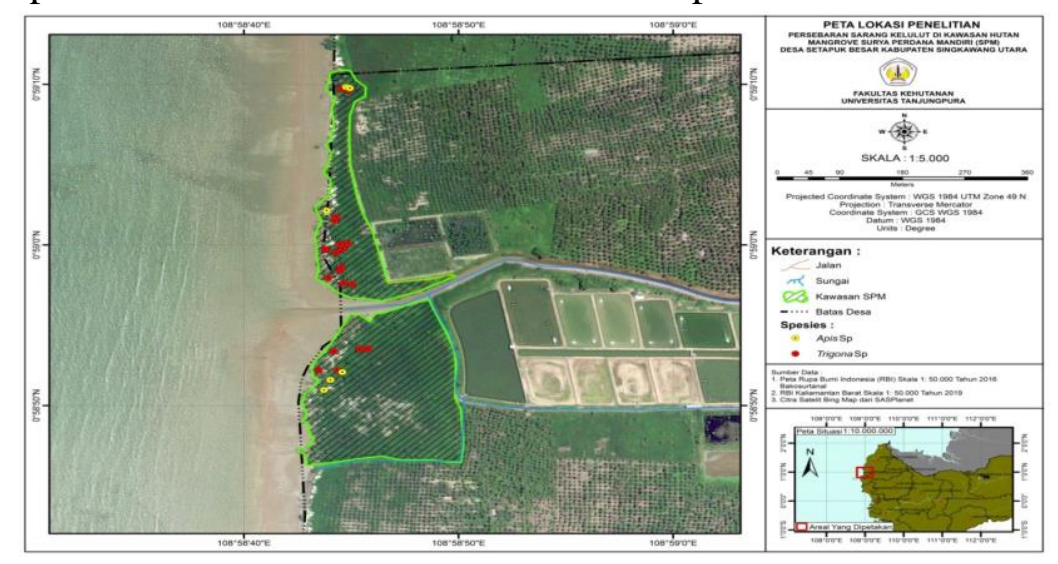

\section{Gambar 1. Peta Lokasi Penelitian (Research Location Map)}

\section{HASIL DAN PEMBAHASAN}

Lebah kelulut yang berhasil teridentifikasi di kawasan Hutan Mangrove Surya Perdana Mandiri (SPM) ada 2 (dua) jenis, yaitu kelulut hitam besar (Heterotrigona itama Cockerell) dan kelulut hitam kecil (Tetragonula laeviceps Smith).

\section{Jenis Lebah Kelulut}

Heterotrigona itama Cockerell atau disebut juga kelulut hitam besar banyak ditemukan bersarang dipohon Avicennia lanata. Iqbal et al (2016), menyatakan bahwa lebah Trigona spp hidup berkoloni dengan membangun sarang pada batang pohon kayu atau bambu, pilar bangunan, celah-celah bebatuan dan tanah. Kelulut ini berukuran antara 9-10 mm. H.itama merupakan jenis yang menjadi prioritas masyarakat untuk dibudidayakan, karena lebih mudah beradaptasi dan mempunyai produksi madu yang lebih banyak 
dibandingkan T.laeviceps. Sanjaya et al (2019), menyatakan bahwa H.itama merupakan lebah tak bersengat yang termasuk dalam genera Heterotrigona, dimana genera ini memiliki ciri yang mudah dibedakan yaitu memiliki ukuran tubuh yang lebih besar, dengan ukuran tubuh dapat mencapai $9 \mathrm{~mm}$. Jenis ini juga merupakan jenis yang mudah beradaptasi diberbagai tempat bersarang. Habitat lebah kelulut banyak dijumpai di daerah tropis dan subtropis seperti di Amerika Selatan, Australia dan Asia Tenggara (Michener, 2007).

Tetragonula laeviceps Smith atau disebut kelulut hitam kecil. Kelulut ini memiliki tubuh yang lebih kecil dibandingkan dengan $H$. itama, dengan ukuran tubuh berkisar antara 5-6 mm. $T$. laeviceps banyak ditemukan didalam



A batang pohon dan memiliki sifat lebih agresif saat sarang mereka didekati dibandingkan jenis $H$. itama. Menurut masyarakat setempat $T$. laeviceps sulit dibudidayakan, serta menghasilkan madu yang lebih sedikit dibandingakan jenis $H$. itama. Sanjaya et al (2019), menyatakan bahwa jenis $T$. laeviceps merupakan jenis trigona yang berukuran tubuhnya standar akan tetapi memiliki sifat yang sangat tangguh disbanding jenis trigona yang lainnya. Trigona ini mampu hidup di daerah yang miskin pakan, bahkan dapat ditemukan hidup dalam suhu yang ekstrim. Syafrizal (2014) menyatakan bahwa ukuran tubuh sangat mempengaruhi jarak terbang lebah dalam mencari makanan, semakin kecil tubuh lebah maka semakin jauh jarak terbang lebah.



B

Gambar 2. Jenis Lebah Kelulut (Type of kelulut bees): a. Heterotrigona itama Cockerell, b. Tetragonula laeviceps Smith

\section{Bentuk Pintu Masuk Sarang}

Sarang kelulut paling banyak ditemukan bersarang pada pohon $A$. lannata (api-api), dimana jenis pohon ini banyak ditemukan dilokasi penelitian dan memiliki batang yang lebih besar dibanding jenis tanaman mangrove yang lainnya. Keberadaan sarang ditandai dengan bangunan yang berfunsi sebagai pintu masuk sarang (entrance). 
Tabel 1. Bentuk Pintu Masuk Sarang Heterotrigona itama (The shape of entrance Heterotrigona itama nest)

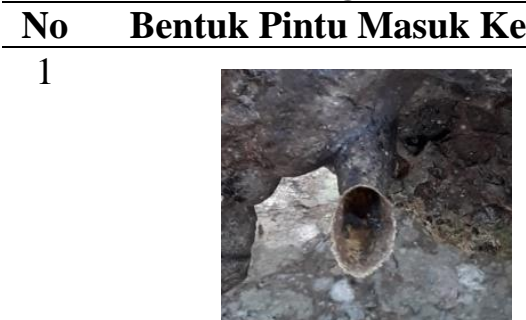

2

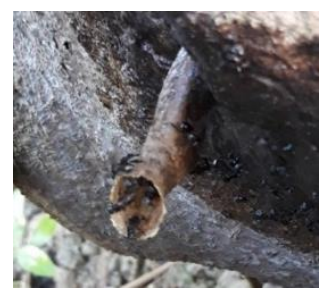

3

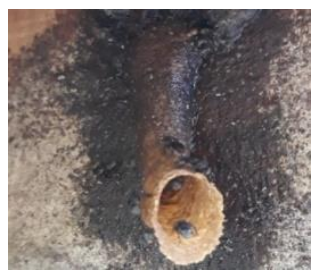

4

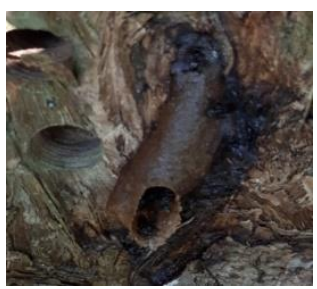

5



6

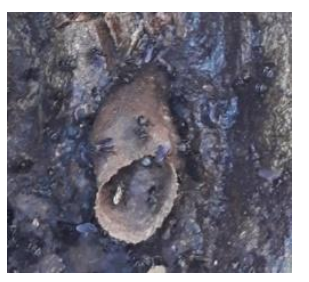

Keterangan

- Bentuk pintu masuk berupa corong pendek dan besar, dengan lebar pintu masuk $12 \mathrm{~mm}$

- Pintu masuknya berwarna hitam

- Sarang ditemukan di sarang buatan/stup budidaya

- Tidak ditemukan propolis di sekitar pintu masuk

- Terdapat lebah pekerja di sekitar sarang

- Bentuk pintu masuk berupa corong panjang dan ramping, dengan lebar pintu masuknya $10 \mathrm{~mm}$

- Pintu masuk berwarna kuning keemasan

- Sarang ditemukan di sarang buatan/stup budidaya

- Ditemukannya propolis di sekitar pintu masuk sebagai perangkap bagi predator

- Terdapat lebah pekerja di sekitar sarang

- Bentuk pintu masuk berupa corong panjang dan besar, dengan lebar pintu masuknya $14 \mathrm{~mm}$

- Pintu masuk berwarna kuning keemasan

- Sarang ditemukan di sarang buatan/stup budidaya

- Ditemukannya propolis di sekitar pintu masuk

- Terdapat lebah pekerja di sekitar sarang

- Bentuk pintu masuk berupa corong panjang dan ramping, dengan lebar pintu masuk $9 \mathrm{~mm}$

- Pintu masuk berwarna coklat tua

- Sarang ditemukan di sarang alami/dalam pohon

- Ditemukannya sedikit propolis di sekitar pintu masuknya

- Terdapat lebah pekerja di sekitar sarang

- Bentuk pintu masuk berupa corong panjang dan ramping, dengan lebar pintu masuknya $9 \mathrm{~mm}$

- Corong berwarna coklat muda

- Sarang ditemukan di sarang alami/dalam pohon

- Ditemukannya propolis di sekitar pintu masuknya

- Terdapat lebah pekerja di sekitar sarang

- Bentuk pintu masuk berupa corong pendek dan besar, dengan lebar pintu masuknya $20 \mathrm{~mm}$

- Corong berwarna coklat tua

- Sarang ditemukan di sarang alami/dalam pohon

- Ditemukannya propolis di sekitar pintu masuknya

- Terdapat lebah pekerja di sekitar sarang
Bentuk pintu sarang $H$. itama ditemukan mempunyai pintu masuk berupa corong dan hampir semua terdapat propolis di sekitarnya (Tabel
1). Pintu masuk jenis $H$. itama memiliki tekstur yang tipis dan lembut, serta terdapat propolis di sekitar pintu masuk yang digunakan sebagai perangkap bagi 
para predator dan ditemukan kasta pekerja yang beterbangan disekitarnya. Bentuk pintu masuk ada yang berupa corong panjang maupun pendek dengan permukaan yang lebar hingga ramping. Panjang corong berukuran antara $4 \mathrm{~cm}-$ $6 \mathrm{~cm}$, dengan lebar berkisar antara 10 $\mathrm{mm}-20 \mathrm{~mm}$. Selain itu, pintu masuk yang ditemukan berwarna kuning emas, coklat, hingga hitam. Menurut Roubik (2006) sarang trigona memiliki bentuk pintu masuk yang beragam, seperti berbentuk corong, bulat tidak beraturan atau tanpa tonjolan (corong) npada pintu masuknya. Menurut Syafrizal et al (2014), bahan dasar penyusun sarang berbeda-beda pada tiap jenis lebah Trigona spp dengan bentuk warna dan aroma yang dipengaruhi oleh jenis tumbuhan sumber resinnya. Ukuran tubuh jenis lebah kelulut mempengaruhi ukuran lubang sarang lebah, semakin besar ukuran tubuh lebah, maka semakin besar juga lubang sarangnya.

Tabel 2. Bentuk Pintu Masuk Sarang Tetragonula laeviceps (The shape of entrance Tetragonula laeviceps nest)

\begin{tabular}{|c|c|c|}
\hline No & Bentuk Pintu Masuk Kelulut & Keterangan \\
\hline 1 & & $\begin{array}{l}\text { - Tidak terdapat corong pada sarang dan hanya } \\
\text { berupa lubang sebagai pintu masuknya } \\
\text { - Ditemukan pada sarang buatan/stup budidaya } \\
\text { - Tidak terdapat propolis di sekitar sarang } \\
\text { - Terdapat lebah pekerja di sekitar sarang } \\
\text { NB: Panah merupakan bentuk pintu masuk kelulut } \\
\text { berupa lubang. }\end{array}$ \\
\hline 2 & & $\begin{array}{l}\text { - Tidak terdapat corong pada sarang dan hanya } \\
\text { berupa lubang sebagai pintu masuknya } \\
\text { - Ditemukan pada sarang alami/dalam pohon } \\
\text { - Tidak terdapat propolis di sekitar sarang } \\
\text { - Terdapat lebah pekerja di sekitar sarang } \\
\text { NB: Panah merupakan bentuk pintu masuk kelulut } \\
\text { berupa lubang. }\end{array}$ \\
\hline 3 & & $\begin{array}{l}\text { - Tidak terdapat corong pada sarang dan hanya } \\
\text { berupa lubang sebagai pintu masuknya } \\
\text { - Ditemukan pada sarang alami/dalam pohon } \\
\text { - Tidak terdapat propolis di sekitar sarang } \\
\text { - Terdapat lebah pekerja di sekitar sarang } \\
\text { NB: Panah merupakan bentuk pintu masuk kelulut } \\
\text { berupa lubang. }\end{array}$ \\
\hline 4 & & $\begin{array}{l}\text { - Tidak terdapat corong pada sarang dan hanya } \\
\text { berupa lubang sebagai pintu masuknya } \\
\text { - Ditemukan pada sarang alami/dalam pohon } \\
\text { - Tidak terdapat propolis di sekitar sarang } \\
\text { - Terdapat lebah pekerja di sekitar sarang } \\
\text { NB: Panah merupakan bentuk pintu masuk kelulut } \\
\text { berupa lubang. }\end{array}$ \\
\hline
\end{tabular}


Bentuk pintu masuk jenis $T$. laeviceps berbeda dari jenis $H$. itama, dimana pintu masuknya tidak memiliki corong sebagai penanda sarang, akan tetapi hanya berupa lubang sebagai pintu keluar masuk sarang. Selain itu pada T. laeviceps tidak ditemukan adanya propolis, namun tetap ditemukan kasta pekerja yang berada disekitar sarang. Ukuran lubang sarang berkisar antara $8 \mathrm{~mm}-10 \mathrm{~mm}$. Menurut Sadam et al (2016), bentuk pintu masuk (entrance) jenis T.laeviceps kebanyakan hanya berbentuk seperti lubang. Iqbal et al (2016) menyatakan bahwa pintu masuk sarang bukan hanya berfungsi sebagai jalan keluar dan masuknya sarang, tetapi juga berfungsi sebagai penanda sarang.

\section{KESIMPULAN}

Jenis kelulut yang ditemukan di kawasan hutan mangrove Surya Perdana Mandiri sebanyak 2 jenis yaitu Heterotrigona itama Cockerell dan Tetragonula laeviceps Smith. Lebah $H$. itama memiliki 6 bentuk pintu masuk dan jenis T. laeviceps memiliki 4 bentuk pintu. Lebah $H$. itama memiliki corong pada pintu masuk dan terdapat propolis yang ada disekitar sarang. Pintu masuk H. itama memiliki bentuk yang berbeda berupa corong panjang serta ramping dan corong pendek dan besar. Selain itu, corong tersebut memiliki warna yang beragam berupa warna hitam, kuning keemasan, coklat muda, dan coklat tua. Sedangkan jenis T. laeviceps tidak memiliki corong atau pintu masuk sarang. Jenis ini hanya membuat lubang sebagai tempat keluar masuk sarang dan tidak ditemukan adanya propolis di sekitar sarang.

\section{DAFTAR PUSTAKA}

Azlan A, Yoza D, Mardiansyah M. 2016. Tingkat Keberhasilan Perpindahan Koloni Trigona spp. Pada Sarang Buatan Di Hutan Larangan Adat Desa Rumbio Kabupaten Kampar. JOM Faperta UR. 3(2), 1-7.

Hidayatullah M. 2016. Madu Mangrove Hasil Hutan Bukan Kayu Potensial. Warta Cendana. IX (2), $1-32$.

Iqbal M, Defri Y, Budiani ES. 2016. Karakteristik Habitat Trigona spp. Di Hutan Larangan Adat Desa Rumbio Kabupaten Kampar. Jom Faperta UR Vol 3 No 2.

Manuhuwa E, Loiwatu M, Lamberkabel JSA, Rumaf I. 2013. Produksi Madu, Propolis Dan Roti Lebah Tanpa Sengat, (Trigona spp) Dalam Sarang Bambu. Proisiding Seminar Nasional Masyarakat Peneliti Kayu Indonesia (MAPEKI) XVI. 251-259.

Michener CD. 2007. The Bees of the World. Baltimore. Uviversity of Kansas Natural History Museum and Biodiversity Research Center and Entomology Program, Department of Ecology and Evolutionary Biology.

Priccillia RH, Jasmi, Amri E. 2018. Model Gerbang (Hymnoptera: Meliponidae) Untuk Penangkaran Di Korong Kuliek Sungai Buluah Timur Batang Anai Kabupaten Padang Pariaman. 1-7. 
Roubik DW. 2006. Stingless Bee Nesting Biology. Apidologie. 37: 124-143.

Sadam B, Hariani N, Fachmi S. 2016. Jenis Lebah Madu Tanpa Sengat (Stingless Bee) di Tanah Merah Samarinda. Prosiding Seminar Sains dan Teknologi MIPA UNMUL.374-378.

Sanjaya V, Astiani D, Sisilia L. 2019. Studi Habitat Dan Sumber Pakan Lebah Kelulut Di Kawasan Cagar Alam Gunung Nyiut Desa Pisak Kabupaten Bengkayang. Jurnal Hutan Lestari. 7(2), 786-798.

Syafrizal, Bratawinata AA, Sila M, Marji DL. 2012. Jenis Lebah
Kelulut (Trigona sp) Di Hutan Pendidikan Lempake. Mulawarman Scientifie. 11(1), 11-18.

Syafrizal, Tarigan D, Yusuf R. 2014. Keragaman dan Habitat Lebah Trigona pada Hutan Sekunder Tropis Basah di Hutan Pendidikan Lempake, Samarinda, Kalimantan Timur. Jurnal Teknologi Pertanian. 9(1), 34-38.

Yuliana R, Sutariningsih E, Santoso HB, Hendarto KA, Riendrasari SD. 2015. Daya Antmikroba Sarang Lebah Madu Trigona spp. Terhadap Mikroba Patogen. Bioedukasi. 8(1), 67-72. 